AgnieszKa Pach-Gurgul

Uniwersytet Ekonomiczny w Krakowie, Polska

\title{
Energetyka odnawialna Unii Europejskiej w warunkach kryzysu gospodarczego
}

\section{Renewable energy in the European Union in the context of economic crisis}

Streszczenie: Współcześnie wykorzystywanie energii odnawialnej zarówno w Unii Europejskiej (UE), jak i na całym świecie wydaje się nieuniknione $\mathrm{z}$ wielu powodów. Jednym z podstawowych są korzyści ekologiczne związane z uniknięciem emisji gazów cieplarnianych. Kolejnym jest zwiększenie bezpieczeństwa energetycznego UE poprzez dywersyfikację dostaw energii i decentralizację jej wytwarzania. Ponadto wykorzystanie energii odnawialnej ogranicza zapotrzebowanie na surowce konwencjonalne, takie jak ropa, gaz czy węgiel. W przypadku wykorzystywania odnawialnych źródeł energii nie występuje problem ich wyczerpywania się, a co za tym idzie odnawialności zasobów. Te wszystkie atuty nabierają coraz większego znaczenia w Unii Europejskiej, zwłaszcza w dobie rosnących cen surowców energetycznych, powtarzających się kryzysów gazowych czy dekarbonizacji gospodarki.

Kryzys gospodarczy wywołał jednak dyskusję w całej Unii Europejskiej na temat kosztów związanych z produkcją energii elektrycznej z odnawialnych źródeł energii. Walka z bezrobociem i długiem publicznym, a także spadająca konkurencyjność unijnej gospodarki, która powiązana jest z wysokimi kosztami energii elektrycznej, postawiła wiele krajów (nawet liderów w tej branży) w sytuacji przymusu ograniczenia wsparcia dla tych źródeł energii i wyhamowania tempa ich rozwoju.

\begin{abstract}
Abstact: Nowadays, the use of renewable energy in the European Union, as well as around the world seems to be unavoidable due to many factors. One of the main reasons are environmental benefits related to greenhouse gases emissions avoidance. Another very important result is the increase of the EU energy security through energy supplies diversification and the decentralization of production. Moreover, the use of renewable energy reduces the need for conventional raw materials such as oil, gas, or coal. The problem of depletion and regeneration of resources does not exist while using renewable energy sources. All these advantages are becoming increasingly important for the European Union, especially in times of rising prices of raw materials, often gas crises or economy decarbonisation process.

Nevertheless, the economic crisis sparked a debate all across the European Union, on the costs related to electricity production from renewable energy sources. The fight against unemployment, public debt and the declining competitiveness of the EU economy, which is also connected with high electricity
\end{abstract}


costs, forced a number of countries (even the leaders in the industry) to reduce support for these energy sources, which also caused the slowdown in their development.

Słowa kluczowe: bezpieczeństwo energetyczne; kryzys gospodarczy; odnawialne źródła energii; pakiet energetyczno-klimatyczny; polityka energetyczna UE; system cen gwarantowanych

Keywords: energy security; economic crisis; renewable energy sources; energy-climate package; energy policy UE; Feed in Tariffs - FiT EU

\section{WsTĘP}

Polityka energetyczna i ekologiczna Unii Europejskiej w ostatnich latach jest ukierunkowywana w dużej mierze na wsparcie rozwoju energetyki odnawialnej. Przyczyn rozwoju odnawialnych źródeł energii jest wiele, ale za najważniejsze uważa się zwiększenie bezpieczeństwa energetycznego Unii Europejskiej, potencjalne zmniejszenie importu paliw kopalnych spoza Unii Europejskiej, wykreowanie nowych miejsc pracy związanych z tym sektorem. Ponadto rozwój odnawialnych źródeł energii wpisuje się w ambitny plan utworzenia niskoemisyjnej gospodarki unijnej. Ich podstawowym atutem jest to, że oprócz efektu produkcyjnego (energii) generują efekt ekologiczny, polegający na zmniejszeniu zużycia paliw konwencjonalnych oraz na ograniczeniu emisji szkodliwych substancji do atmosfery, takich jak np. $\mathrm{CO}_{2}$.

W związku z tym Unia Europejska nadała priorytet rozwojowi odnawialnych źródeł energii, ustanawiając ambitny cel zwiększenia ich udziału do $20 \% \mathrm{w}$ ogólnym bilansie energetycznym UE do 2020 roku. Jest to cel niezwykle trudny do osiągnięcia, gdyż inwestycje w odnawialne źródła energii są specyficznymi inwestycjami rzeczowymi, potrzebującymi wsparcia finansowego państwa (często kosztem innych branż, sektorów). Są to inwestycje długoterminowe, wymagające szeregu uregulowań prawnych oraz zapewniających stopę zwrotu inwestorowi.

Wydaje się jednak, iż kryzys gospodarczy zmienił priorytety gospodarcze UE. Walka z bezrobociem, długiem publicznym i deficytem budżetowym w krajach strefy euro oraz zmniejszenie konkurencyjności unijnej gospodarki postawiły na nowo pytanie: czy Unię stać w sytuacji kryzysu na rozwój kosztownych odnawialnych źródeł energii i ich subsydiowanie?

Celem niniejszego artykułu jest:

- określenie roli odnawialnych źródeł energii w bilansie energetycznym Unii Europejskiej,

- określenie perspektyw rozwoju odnawialnych źródeł energii w UE do 2020 roku,

- przedstawienie wpływu kryzysu gospodarczego na rozwój odnawialnych źródeł energii w Unii Europejskiej oraz w poszczególnych krajach członkowskich. 


\section{ROLA ODNAWIALNYCH ŹRÓDEŁ ENERGII W BILANSIE ENERGETYCZNYM}

\section{UNII EUROPEJSKIEJ}

Według najprostszej klasyfikacji źródła energii dzieli się na nieodnawialne i odnawialne. Źródła nieodnawialne obejmują energię zawartą w kopalnych paliwach mineralnych, takich jak: węgiel kamienny i brunatny, ropa naftowa czy też gaz ziemny. Źródła te występują jednak w ilościach skończonych i ściśle określonych. Tempo ich eksploatacji rosło gwałtownie w ubiegłym stuleciu i nadal jest wysokie, w efekcie czego światowe zasoby tych surowców zostały poważnie zubożone.

Z kolei odnawialne źródła energii (OZE) charakteryzują się tą szczególną właściwością, że ich wykorzystanie w danym miejscu nie ogranicza ogólnie dostępnych zasobów energii: promieniowania słonecznego, wiatru, rzek, pływów i prądów morskich, biomasy (Ligus, 2010).

W tab. 1 został przedstawiony podział OZE oraz możliwości uzyskania energii, a także techniczne możliwości przemiany energii.

Tab. 1. Podział odnawialnych źródeł energii oraz techniczne możliwości jej konwersji

\begin{tabular}{|c|c|c|c|}
\hline $\begin{array}{c}\text { Pierwotne źródła } \\
\text { energii }\end{array}$ & $\begin{array}{l}\text { Naturalne procesy } \\
\text { przemiany energii }\end{array}$ & Techniczne procesy & $\begin{array}{c}\text { Forma uzyskanej } \\
\text { energii }\end{array}$ \\
\hline woda & $\begin{array}{l}\text { opady, parowanie, } \\
\text { topnienie lodu i śniegu }\end{array}$ & elektrownie wodne & energia elektryczna \\
\hline \multirow[t]{2}{*}{ wiatr } & ruch atmosfery & elektrownie wiatrowe & $\begin{array}{l}\text { energia elektryczna } \\
\text { i cieplna }\end{array}$ \\
\hline & energia fal & elektrownie falowe & energia elektryczna \\
\hline \multirow{6}{*}{$\begin{array}{l}\text { promieniowanie } \\
\text { słoneczne }\end{array}$} & prądy oceaniczne & $\begin{array}{l}\text { elektrownie } \\
\text { wykorzystujące } \\
\text { prądy oceaniczne }\end{array}$ & energia elektryczna \\
\hline & \multirow[t]{2}{*}{$\begin{array}{l}\text { nagrzewanie } \\
\text { powierzchni Ziemi } \\
\text { i atmosfery }\end{array}$} & $\begin{array}{l}\text { elektrownie } \\
\text { wykorzystujące ciepło } \\
\text { oceanów }\end{array}$ & energia elektryczna \\
\hline & & pompy ciepła & energia cieplna \\
\hline & \multirow[t]{3}{*}{ promienie słoneczne } & $\begin{array}{l}\text { kolektory i cieplne } \\
\text { elektrownie słoneczne }\end{array}$ & energia cieplna \\
\hline & & $\begin{array}{l}\text { fotoogniwa i elektrownie } \\
\text { słoneczne }\end{array}$ & energia elektryczna \\
\hline & & fotoliza & paliwa \\
\hline \multirow[t]{2}{*}{ biomasa } & \multirow[t]{2}{*}{ produkcja biomasy } & $\begin{array}{l}\text { ogrzewanie i elektrownie } \\
\text { cieplne }\end{array}$ & $\begin{array}{l}\text { energia cieplna } \\
\text { i elektryczna }\end{array}$ \\
\hline & & urządzenia przetwarzające & paliwa \\
\hline rozpad izotopów & źródła geotermalne & $\begin{array}{l}\text { ogrzewanie i elektrownie } \\
\text { geotermalne }\end{array}$ & $\begin{array}{l}\text { energia cieplna } \\
\text { i elektryczna } \\
\end{array}$ \\
\hline grawitacja & pływy wód & elektrownie pływowe & energia elektryczna \\
\hline
\end{tabular}

Źródło: opracowanie własne na podstawie W.M. Lewandowski, Proekologiczne odnawialne źródła energii 
W opublikowanym w 1972 roku przez Klub Rzymski raporcie Granice wzrostu (Meadows, Meadows, Randers, Behrens, 1972) przedstawiony został pesymistyczny scenariusz dla całego świata, przewidujący m.in. wyczerpywanie się surowców naturalnych (do 1990 roku miały wyczerpać się zasoby ropy i gazu) oraz występowanie w przyszłości przerw w dostawach energii w wyniku niedoborów tych surowców. Prognozy te nie sprawdziły się, jednak do dziś niektórzy eksperci uważają, że światowa produkcja ropy naftowej osiąga swoje maksimum, tzw. peak oil, co oznacza, że kolejne zasoby będą trudniejsze do odkrycia i pozyskania. Inni dowodzą, że ciągłe odkrywanie nowych zasobów, czy to ropy naftowej w Brazylii, czy gazu łupkowego w USA, czy też innych surowców mineralnych, odsuwa widmo braku paliw i nie potwierdza teorii o wyczerpalności zasobów. Dyskusja owocuje poszukiwaniem substytutów surowcowych, rozwojem nowoczesnych technologii czy też właśnie rozwojem odnawialnych źródeł energii (Glachant, Lévêque, 2009).

W związku z wyczerpalnością zasobów, a także na skutek takich wydarzeń, jak szoki naftowe, kryzysy gazowe, rosnące ceny surowców energetycznych, Unia Europejska mocno zaangażowała się w rozwój OZE.

Promowanie i rozwój OZE jest jednym z priorytetów polityki energetycznej UE i wpisuje się w realizację trzech głównych celów polityki energetycznej UE zakładających:

1. Bezpieczeństwo energetyczne krajów UE.

2. Konkurencyjność gospodarki unijnej.

3. Ochronę środowiska naturalnego przed szkodliwymi skutkami wytwarzania i dostarczania energii.

Ponadto wykorzystywanie lokalnych, odnawialnych zasobów energetycznych pozwala na dywersyfikację źródeł zaopatrzenia w energię, co ma bardzo istotne znaczenie w kontekście silnego uzależnienia UE od importu kopalnych nośników energii. Oprócz zwiększenia stopnia samowystarczalności energetycznej stosowanie OZE przynosi także korzyści ekologiczne. Najważniejszą cechą OZE z punktu widzenia ochrony środowiska jest możliwość substytucji wysokoemisyjnych paliw kopalnych, co jest kluczowe dla realizacji unijnej idei dekarbonizacji gospodarki i polityki klimatycznej. Unia Europejska liczy również na korzyści społeczne związane ze stosowaniem OZE, takie jak możliwość stworzenia dodatkowych miejsc pracy oraz aktywizacja gospodarcza nowych regionów.

W 2011 roku całkowite potrzeby energetyczne UE, wyrażone jako zużycie energii brutto, pokrywane były następująco: $34 \%$ - ropa naftowa, 24\% - gaz ziemny, $15 \%$ - paliwa stałe, takie jak węgiel, 14\% - energia jądrowa i 13\% - odnawialne źródła energii, takie jak hydroenergia czy energia wiatrowa (ryc. 1).

Udział energii z odnawialnych źródeł energii jest bardzo zróżnicowany w poszczególnych państwach członkowskich. Podlega on znacznemu zróżnicowaniu w poszczególnych państwach (ryc. 2) i ewoluuje ze względu na ich uwarunkowania geograficzne, takie jak występowanie zasobów naturalnych i dostęp do nich, kształt polityki przyjętej przez poszczególne państwa, np. zachęta finansowa, postęp techniczny, wymogi dotyczące dekarbonizacji i rozwój rynku wewnętrznego. 


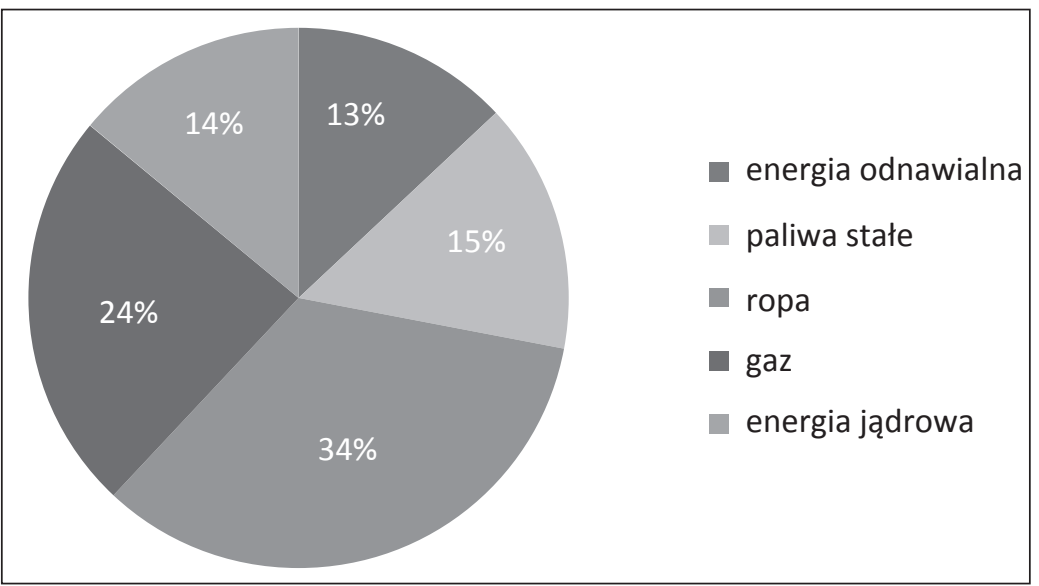

Ryc. 1. Zużycie energii brutto w Unii Europejskiej w 2011 roku

Źródło: opracowanie własne na podstawie: Wyzwania i polityka w zakresie energii, sprawy przedłożone przez Komisję na posiedzenie Rady Europejskiej w dniu 22 maja 2013 roku

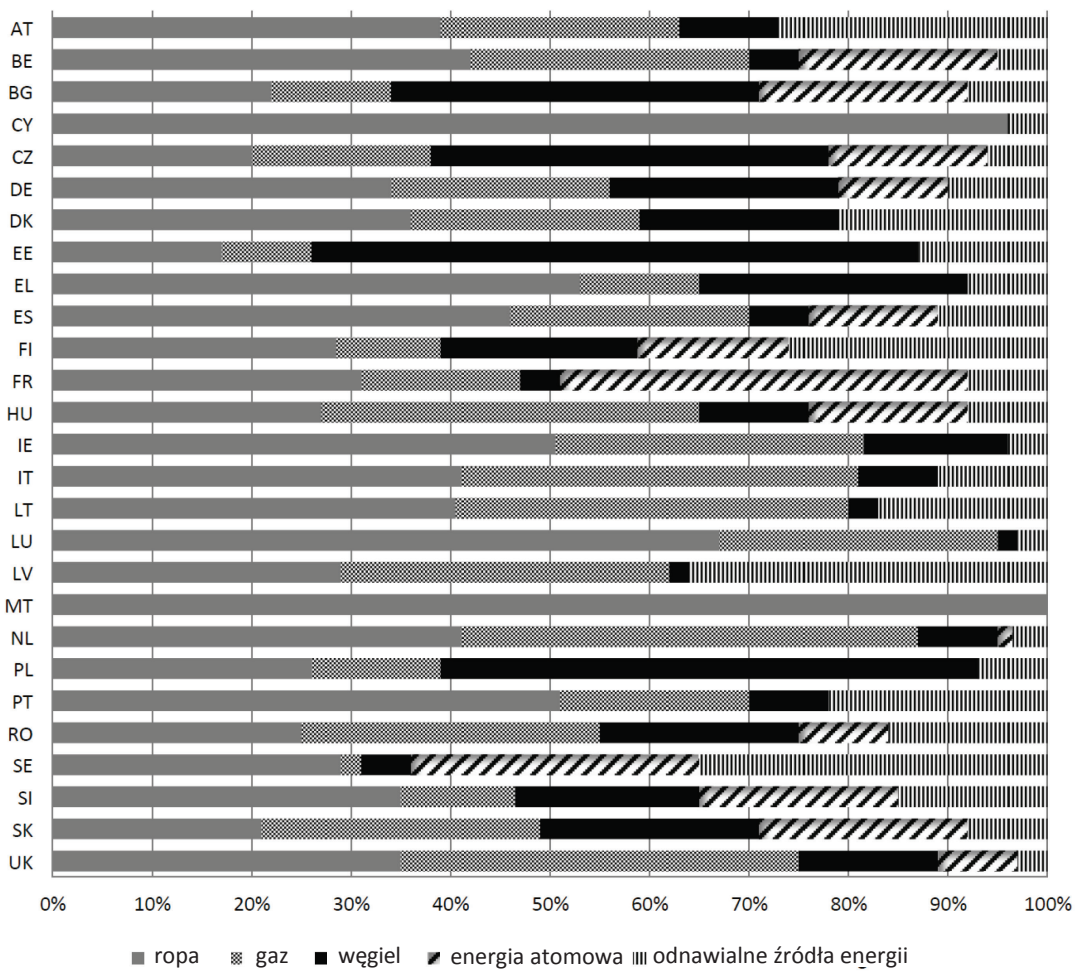

Ryc. 2. Koszyki energetyczne poszczególnych krajów członkowskich w 2012 roku

Źródło: opracowanie własne na podstawie: Wyzwania i polityka w zakresie energii, sprawy przedłożone przez Komisję na posiedzenie Rady Europejskiej w dniu 22 maja 2013 roku 
Największy udział OZE w koszyku energetycznym występuje w Szwecji, na Łotwie, w Finlandii, Austrii i Danii.

Udział odnawialnych źródeł energii w ogólnym bilansie energetycznym UE rośnie systematycznie. Wpływ na tę sytuację mają przede wszystkim argumenty ekologiczne, względy bezpieczeństwa energetycznego, ale również przyjęty w marcu 2008 roku pakiet energetyczno-klimatyczny.

\section{PerspeKTYWy ROZWOJU ODNAWIALNYCH ŹRÓDEŁ ENERGII W UNII EUROPEJSKIEJ DO 2020 ROKU}

Przyjęty w marcu 2008 roku pakiet energetyczno-klimatyczny przedstawia zamierzenia w zakresie polityki energetycznej UE, potocznie określane jako „3×20\%”, które mają być spełnione przez państwa członkowskie do 2020 roku. Obejmują one:

1. Zwiększenie udziału energii ze źródeł odnawialnych (OZE) do 20\% w łącznym bilansie energetycznym Unii Europejskiej.

2. Redukcję $\mathrm{CO}_{2}$ o $20 \%$, w stosunku do poziomu emisji z 1990 roku.

3. Ograniczenie łącznego zużycia energii pierwotnej w Unii Europejskiej o 20\% w stosunku do prognozy podstawowej dla roku 2020, przedstawionej w 2007 roku.

Dodatkowo ustalono zwiększenie do 10\% udziału biopaliw w ogólnym zużyciu paliw przez transport na terenie UE (Zielona księga. Ramy polityki w zakresie klimatu i energii do roku 2030, 2013).

W skład pakietu weszła dyrektywa RES (Renewable Energy Sources - Dyrektywa Parlamentu Europejskiego i Rady w sprawie promowania stosowania energii ze źródeł odnawialnych, 2008), która zobowiązała państwa członkowskie do osiągnięcia celu, jakim jest 20-procentowy udział energii ze źródeł odnawialnych w całościowym bilansie energetycznym Unii Europejskiej do 2020 roku (National Overall Share and Targets for the Share of Energy from Renewable Sources in Gross Final Consumption of Energy in 2020). Dyrektywa ustanowiła dla poszczególnych państw ogólny limit docelowego udziału energii odnawialnej (tab. 2) oraz precyzyjny sposób jego wyliczenia, przyjmując jako wartość odniesienia udział energii odnawialnej z 2005 roku.

W przypadku postanowień dotyczących udziału OZE w poszczególnych krajach osiągnięto kompromis, który polegał na tym, że wyznaczony cel nie będzie identyczny dla wszystkich państw członkowskich. Przykładowo dla Danii, w której udział energii z odnawialnych źródeł w całkowitej konsumpcji w 2005 roku wynosił 17\%, zaplanowano udział 30\% w 2020 roku, zaś dla Polski, w której udział energii z odnawialnych źródeł w całkowitej konsumpcji w 2005 roku wynosił 7,2\%, zaplanowano udział 15\% w 2020 roku (Pach-Gurgul, 2012).

Jednak zwiększenie udziału energii odnawialnej w strukturze produkcji i zużycia energii elektrycznej UE jest zadaniem trudnym i bardzo kosztownym. Wymaga bowiem stosowania rozwiązań wspierających wzrost tego udziału, prowadzących jednocześnie do obniżki kosztów wytwarzania energii odnawialnej, a w konsekwencji poprawy jej konkurencyjności. 
Tab. 2. Narodowe udziały energii z odnawialnych źródeł w całkowitej konsumpcji energii w 2005 roku i w 2020 roku

\begin{tabular}{|c|c|c|}
\hline Kraje UE-27 & $\begin{array}{c}\text { Udział energii z odnawialnych } \\
\text { źródeł w całkowitej konsumpcji } \\
\text { energii w } 2005 \text { roku } \\
\text { (w \%) }\end{array}$ & $\begin{array}{l}\text { Ustalony udział energii } \\
\text { z odnawialnych źródeł } \\
\text { w całkowitej konsumpcji } \\
\text { energii w } 2020 \text { roku } \\
\text { (w \%) }\end{array}$ \\
\hline Austria & 23,3 & 34 \\
\hline Belgia & 2,2 & 13 \\
\hline Bułgaria & 9,4 & 16 \\
\hline Cypr & 2,9 & 13 \\
\hline Czechy & 6,1 & 13 \\
\hline Dania & 17,0 & 30 \\
\hline Estonia & 18,0 & 25 \\
\hline Finlandia & 28,5 & 38 \\
\hline Francja & 10,3 & 23 \\
\hline Grecja & 6,9 & 18 \\
\hline Hiszpania & 8,7 & 20 \\
\hline Holandia & 2,4 & 14 \\
\hline Irlandia & 3,1 & 16 \\
\hline Litwa & 32,6 & 40 \\
\hline Luksemburg & 0,9 & 11 \\
\hline Łotwa & 32,6 & 40 \\
\hline Malta & 0,0 & 10 \\
\hline Niemcy & 5,8 & 18 \\
\hline Polska & 7,2 & 15 \\
\hline Portugalia & 20,5 & 31 \\
\hline Rumunia & 17,8 & 24 \\
\hline Słowacja & 6,7 & 14 \\
\hline Słowenia & 16,0 & 25 \\
\hline Szwecja & 39,8 & 49 \\
\hline Węgry & 4,3 & 13 \\
\hline Wielka Brytania & 1,3 & 15 \\
\hline Włochy & 5,2 & 17 \\
\hline
\end{tabular}

Źródło: opracowanie własne na podstawie: National Overall Share and Targets for the Share of Energy from Renewable Sources in Gross Final Consumption of Energy in 2020 (2013 r., 25 września)

Konieczność wsparcia rozwoju energetyki odnawialnej wynika przede wszystkim ze znacznie wyższych kosztów produkcji energii odnawialnej w porównaniu ze źródłami konwencjonalnymi. Przyczyną tego są przede wszystkim wysokie nakłady kapitałowe konieczne do uruchomienia instalacji odnawialnych i podłączenia ich do sieci. Istotną rolę odgrywa 
również nieciągły charakter źródeł odnawialnych i konieczność ich uzupełniania konwencjonalnymi źródłami energii oraz związane z tym koszty bilansowania systemów elektroenergetycznych, jak również niekompletne uregulowania prawne, budzące obawy inwestorów.

Istnieje kilka rodzajów wsparcia rozwoju energetyki odnawialnej stosowanych przez kraje UE (tab. 3).

Tab. 3. Instrumenty wspierania rozwoju odnawialnych źródeł energii

\begin{tabular}{|l|l|l|}
\hline \multicolumn{1}{|c|}{ FINANSOWE } & \multicolumn{1}{|c|}{ ADMINISTRACYJNE } & \multicolumn{1}{c|}{ SIECIOWE } \\
\hline $\begin{array}{l}\text { Systemy wsparcia zakupu energii } \\
\text { z OZE: } \\
\text { - stała cena zakupu } \\
\text { (cena gwarantowana) } \\
\text { - zielone certyfikaty } \\
\text { - przetargi }\end{array}$ & $\begin{array}{l}\text { Ilościowy obowiązek zakupu } \\
\text { energii z OZE }\end{array}$ & $\begin{array}{l}\text { Określenie uzasadnionych } \\
\text { kosztów korzystania z sieci } \\
\text { przesyłowych }\end{array}$ \\
\hline Dotacje i subwencje & $\begin{array}{l}\text { Obowiązek zapewnienia } \\
\text { pierwszeństwa } \\
\text { w świadczeniu usług } \\
\text { przesyłowych energii } \\
\text { elektrycznej z OZE } \\
\text { w krajowym systemie } \\
\text { elektroenergetycznym }\end{array}$ & $\begin{array}{l}\text { Przejrzystość cen dostępu } \\
\text { do sieci }\end{array}$ \\
\hline $\begin{array}{l}\text { Preferencyjnie i nisko oprocentowane } \\
\text { kredyty }\end{array}$ & $\begin{array}{l}\text { Wydawanie świadectw } \\
\text { pochodzenia energii } \\
\text { odnawialnej wraz } \\
\text { z przysługującymi im } \\
\text { prawami majątkowymi }\end{array}$ & $\begin{array}{l}\text { Dopłaty do niezbędnych } \\
\text { modernizacji sieci }\end{array}$ \\
\cline { 2 - 3 } $\begin{array}{l}\text { Wsparcie fiskalne: } \\
\text { - ulgi podatkowe } \\
\text { - zwolnienia z podatku akcyzowego } \\
- \text { niższe stawki podatku VAT }\end{array}$ & przyłącza do sieci \\
\hline
\end{tabular}

Źródło: opracowanie własne na podstawie J. Pyka (red), Szanse i zagrożenia rozwoju rynku energetycznego $w$ Europie i Polsce

Popularną formą wsparcia rozwoju energetyki odnawialnej w krajach członkowskich UE jest mechanizm cen gwarantowanych (Feed in Tariffs - FiT). W przypadku gdy gwarancje cenowe dla energii odnawialnej mają charakter długookresowy, pozwalają inwestorom na dość precyzyjne oszacowanie efektywności inwestycji, w tym okresu zwrotu, co zachęca do inwestowania w tego typu źródła. W połączeniu z obowiązkiem zakupu energii odnawialnej (Quota Obligations - QO) przez spółki dystrybucyjne gwarancje te stanowią istotny czynnik skłaniający banki do współfinansowania projektów z zakresu energetyki odnawialnej (Motowidlak, 2012).

Kolejnym instrumentem wsparcia rozwoju odnawialnych źródeł energii są bodźce podatkowe. Taki sposób pomocy państwom członkowskim UE zapewniają zapisy Dyrektywy 2003/96/UE. Bodźce te mogą przyjmować formę zachęt do podejmowania inwestycji 
w sektorze energetyki odnawialnej (podażowe instrumenty proinwestycyjne) lub rozpoczęcia ich eksploatacji (instrumenty podażowe proprodukcyjne). Poprzez zwolnienia nabywców energii odnawialnej z obowiązków podatkowych bodźce te spełniają także funkcje instrumentu kreującego popyt (instrument popytowy) (Motowidlak, 2012).

Subwencje oraz wszelkiego rodzaju dotacje są bezzwrotną formą finansowego wsparcia realizacji projektów z zakresu energetyki odnawialnej. Nie mają one rynkowego charakteru i są stosowane zazwyczaj we wczesnym stadium rozwoju energetyki odnawialnej. Subsydia bezpośrednie dotyczą głównie prac badawczych i rozwojowych, a także projektowych, natomiast rzadziej zakupu dóbr inwestycyjnych. Bezpośrednie dotowanie inwestycji kapitałowych obejmujących budowę instalacji i obiektów energetyki odnawialnej stanowi w krajach członkowskich UE istotny element systemów wsparcia jej rozwoju ${ }^{1}$.

W celu sprostania nałożonym centralnie obowiązkom w zakresie rozwoju energetyki odnawialnej państwa członkowskie UE opracowały i wdrożyły własne krajowe programy wspomagania i promocji wytwarzania energii odnawialnej. Programy te wynikają bowiem z różnorodności dostępnych systemów wsparcia oraz zróżnicowanych możliwości finansowych poszczególnych państw członkowskich UE. Warto podkreślić, iż finansowanie wspomnianych programów stanowi obciążenie dla budżetów państw członkowskich, co w czasie kryzysu gospodarczego postawiło pod znakiem zapytania dalszy rozwój odnawialnych źródeł energii.

\section{WPŁYW KRYZYSU GOSPODARCZEGO NA ROZWÓJ ODNAWIALNYCH ŹRÓDEE ENERGII W UNII EUROPEJSKIEJ}

Gospodarka Unii Europejskiej od kilku lat znajduje się w kryzysie, który z różnym natężeniem dotyka poszczególne kraje UE. Jego skutkami są: ujemny (bądź niski) przyrost PKB odbijający się na inwestycjach i konsumpcji krajów UE, deficyt budżetowy, rosnący dług publiczny i koszty jego obsługi, a przede wszystkim najwyższy od lat i niespotykany dotychczas w UE poziom bezrobocia. Kryzys gospodarczy w Unii Europejskiej dotknął szczególnie niektóre kraje strefy euro, niespełniające kryteriów makroekonomicznych z Maastricht (Grecję, Irlandię, Włochy, Hiszpanię). Sytuacja w tych krajach nadal jest źródłem poważnych napięć społeczno-politycznych zagrażających procesowi dalszej integracji. Gospodarka europejska staje się mniej konkurencyjna w ujęciu globalnym. Jedną z istotnych przyczyn takiego stanu rzeczy są zbyt wysokie koszty energii, które wynikają z jednostronnej, restrykcyjnej polityki energetycznej i klimatycznej UE, w tym realizacji pakietu energetyczno-klimatycznego i ambitnych celów $3 \times 20 \%$ do 2020 roku, w tym 20\% udziału odnawianych źródeł energii w bilansie energetycznym UE.

W 2010 roku większość krajów unijnych świetnie sobie radziła ze zwiększaniem wykorzystania odnawialnych źródeł energii w swoim bilansie energetycznym, np. Austria, Bułgaria, Niemcy, Dania, Estonia, Litwa, Rumunia, Szwecja, Słowenia. Warto podkreślić, że również Hiszpania i Włochy, kraje mające poważne problemy gospodarcze w czasie kryzysu

${ }^{1}$ Do równie popularnych instrumentów wsparcia zalicza się system zielonych certyfikatów lub system przetargowy. 
gospodarczego, należały do krajów prężnie rozwijających wykorzystanie odnawialnych źródeł energii (tab. 4).

Tab. 4. Postępy we wdrożeniu dyrektywy w sprawie odnawialnych źródeł energii²

\begin{tabular}{|c|c|c|c|c|}
\hline $\begin{array}{c}\text { Państwo } \\
\text { członkowskie }\end{array}$ & $\begin{array}{c}\text { Udział } \\
\text { odnawialnych } \\
\text { źródeł energii } \\
\text { w } 2005 \text { roku }\end{array}$ & $\begin{array}{c}\text { Udział } \\
\text { odnawialnych } \\
\text { źródeł energii } \\
\text { w } 2010 \text { roku }\end{array}$ & Cel pośredni & $\begin{array}{c}\text { Cel wyznaczony } \\
\text { w pakiecie } \\
\text { energetyczno- } \\
\text {-klimatycznym } \\
\text { na } 2020 \text { rok }\end{array}$ \\
\hline Austria & $23,3 \%$ & $30,1 \%$ & $25,4 \%$ & $34,0 \%$ \\
\hline Belgia & $2,2 \%$ & $5,4 \%$ & $4,4 \%$ & $13,0 \%$ \\
\hline Bułgaria & $9,4 \%$ & $13,8 \%$ & $10,7 \%$ & $16,0 \%$ \\
\hline Cypr & $2,9 \%$ & $5,7 \%$ & $4,9 \%$ & $13,0 \%$ \\
\hline Czechy & $6,1 \%$ & $9,4 \%$ & $7,5 \%$ & $13,0 \%$ \\
\hline Dania & $17,0 \%$ & $22,2 \%$ & $19,6 \%$ & $30,0 \%$ \\
\hline Estonia & $18,0 \%$ & $24,3 \%$ & $19,4 \%$ & $25,0 \%$ \\
\hline Finlandia & $28,5 \%$ & $33,0 \%$ & $30,4 \%$ & $38,0 \%$ \\
\hline Francja & $10,3 \%$ & $13,5 \%$ & $12,8 \%$ & $23,0 \%$ \\
\hline Niemcy & $5,8 \%$ & $11,0 \%$ & $8,2 \%$ & $18,0 \%$ \\
\hline Wielka Brytania & $1,3 \%$ & $5,0 \%$ & $4,0 \%$ & $15,0 \%$ \\
\hline Grecja & $6,9 \%$ & $9,7 \%$ & $9,1 \%$ & $18,0 \%$ \\
\hline Węgry & $4,3 \%$ & $8,8 \%$ & $6,0 \%$ & $13,0 \%$ \\
\hline Irlandia & $3,1 \%$ & $5,8 \%$ & $5,7 \%$ & $16,0 \%$ \\
\hline Włochy & $5,2 \%$ & $10,4 \%$ & $7,6 \%$ & $17,0 \%$ \\
\hline Łotwa & $32,6 \%$ & $32,6 \%$ & $34,0 \%$ & $40,0 \%$ \\
\hline Litwa & $15,0 \%$ & $19,7 \%$ & $16,6 \%$ & $23,0 \%$ \\
\hline Luksemburg & $0,9 \%$ & $3,0 \%$ & $2,9 \%$ & $11,0 \%$ \\
\hline Malta & $0,0 \%$ & $0,4 \%$ & $2,0 \%$ & $10,0 \%$ \\
\hline Holandia & $2,4 \%$ & $3,8 \%$ & $4,7 \%$ & $14,0 \%$ \\
\hline Polska & $7,2 \%$ & $9,5 \%$ & $8,8 \%$ & $15,0 \%$ \\
\hline Portugalia & $20,5 \%$ & $24,6 \%$ & $22,6 \%$ & $31,0 \%$ \\
\hline Rumunia & $17,8 \%$ & $23,6 \%$ & $19,0 \%$ & $24,0 \%$ \\
\hline Słowacja & $6,7 \%$ & $9,8 \%$ & $8,2 \%$ & $14,0 \%$ \\
\hline Słowenia & $16,0 \%$ & $19,9 \%$ & $17,8 \%$ & $25,0 \%$ \\
\hline Hiszpania & $8,7 \%$ & $13,8 \%$ & $10,9 \%$ & $20,0 \%$ \\
\hline Szwecja & $39,8 \%$ & $49,1 \%$ & $41,6 \%$ & $49,0 \%$ \\
\hline UE & $8,5 \%$ & $12,7 \%$ & $10,7 \%$ & $20,0 \%$ \\
\hline
\end{tabular}

Źródło: opracowanie własne na podstawie Wyzwania i polityka w zakresie energii, sprawy przedłożone przez Komisję na posiedzenie Rady Europejskiej w dniu 22 maja 2013 r.

Pomimo kryzysu w 2011 roku udział energii ze źródeł odnawialnych w zużyciu energii końcowej w UE wynosił 13,0\% w porównaniu z 8,5\% w 2005 roku (Wyzwania i polityka w zakresie energii, 2013).

\footnotetext{
${ }^{2}$ Dyrektywa 2009/28/WE z dnia 23 kwietnia 2009 r.
} 
W celu wsparcia realizacji ogólnego celu Komisja określiła cztery obszary, w których należy zintensyfikować działania (Komunikat Energia odnawialna: istotny uczestnik europejskiego rynku energii (COM, 2012), 271): rynek energii, systemy wsparcia, mechanizmy współpracy i współpraca w regionie Morza Śródziemnego, a obecnie przygotowuje związane z nimi wytyczne (m.in. w sprawie otwarcia wewnętrznego rynku energii elektrycznej, lepszej integracji rynkowej odnawialnych źródeł energii, współpracy i handlu, infrastruktury i konsumentów oraz innowacji technologicznych).

Najwyższy udział energii odnawialnej w swoich bilansach energetycznych odnotowały w 2011 roku: Szwecja (46,8\% przy celu 49\%), Łotwa (33,1\% przy celu 40\%), Finlandia (31,8\% przy celu 38\%) i Austria (30,9\% przy celu 34\%). Pierwszym krajem, który przekroczył cel na 2020 rok, jest Estonia, która osiągnęła blisko 26\% udziału energii odnawialnej w krajowym bilansie energetycznym, podczas gdy jej cel na 2020 rok to $25 \%$. Najniższy udział ,zielonej” energii w UE miały w 2011 roku Malta (0,4\% przy celu 10\%), Luksemburg (2,9\% przy celu $11 \%)$, Wielka Brytania $(3,8 \%$ przy celu $15 \%)$, Belgia $(4,1 \%$ przy celu $13 \%)$ i Holandia (4,3\% przy celu 14\%) (EU Energy, transport and environment indicators, 2013).

Warto podkreślić, iż do połowy 2011 roku Unia była światowym liderem w rozwoju odnawialnych źródeł energii i przeznaczała na ten cel ogromne środki finansowe, większe niż Chiny czy USA (ryc. 3). Nasilające się skutki kryzysu gospodarczego i kryzysu strefy euro spowodowały zdecydowany spadek inwestycji w OZE. Ograniczono również dopływ środków do funduszy i programów ramowych, które stworzono na szczeblu unijnym z myślą o wsparciu rozwoju sektora energetyki odnawialnej UE.

W wielkości mocy instalacji pozyskujących energię z odnawialnych źródeł (wyłączając z tego siłownie rzeczne) prowadzą Chiny, które wyprzedzają pod tym względem Stany Zjednoczone. Dalej są Niemcy, Hiszpania, Włochy, Indie i Japonia. Jednak w przeliczeniu zainstalowanej mocy na głowę mieszkańca hierarchia ta przedstawia się już inaczej: w tej statystyce zdecydowanie prowadzą Niemcy, a za nimi sytuują się Hiszpanie, Włosi, Amerykanie, Japończycy, Chińczycy i Hindusi. To m.in. dlatego Niemcy deklarują całkowite wycofanie się z energetyki jądrowej do 2022 roku.

W 2011 roku Unia była również światowym liderem pod względem wsparcia finansowego dla energii odnawialnej, wyprzedzając nawet tak duże gospodarki, jak Chiny, USA czy Indie (ryc. 4).

Jednak rosnące bezrobocie i zadłużenie państw w czasie kryzysu na nowo wywołały dyskusję, czy poszczególne kraje członkowskie UE stać na rozwój OZE - drogiego źródła energii i czy warto do nich dopłacać. Subsydia, które w ostatnich latach napędzały koniunkturę w branży, w dobie kryzysu i koniecznych oszczędności niestety są traktowane jak ciężar dla budżetu oraz odbiorców finalnych energii. Realne koszty energii ze źródeł odnawialnych okazują się być za wysokie dla wielu europejskich gospodarek. Eksperci nie mają wątpliwości, że mechanizm subsydiowania powinien w jakiejś formie istnieć, bo produkcja energii słonecznej i wiatrowej jest bardzo kosztowna, jednak dotychczasowa dowolność w ustalaniu form i warunków dopłat w ramach Unii nie sprawdza się, zwłaszcza w okresie kryzysu. 


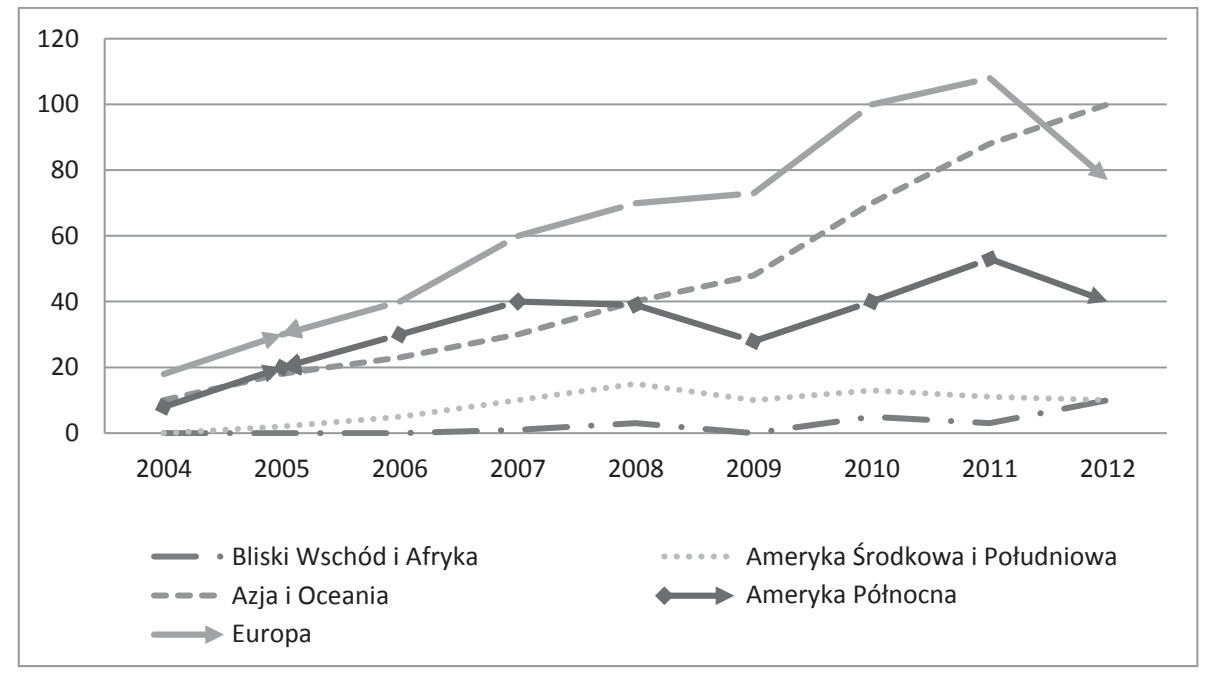

Ryc. 3. Inwestycje w odnawialne źródła energii w latach 2004-2012 (w mld USD) w rozbiciu na regiony

Źródło: Wyzwania i polityka w zakresie energii, poprawy przedłożone przez Komisję na posiedzenie Rady Europejskiej w dniu 22 maja $2013 \mathrm{r}$.

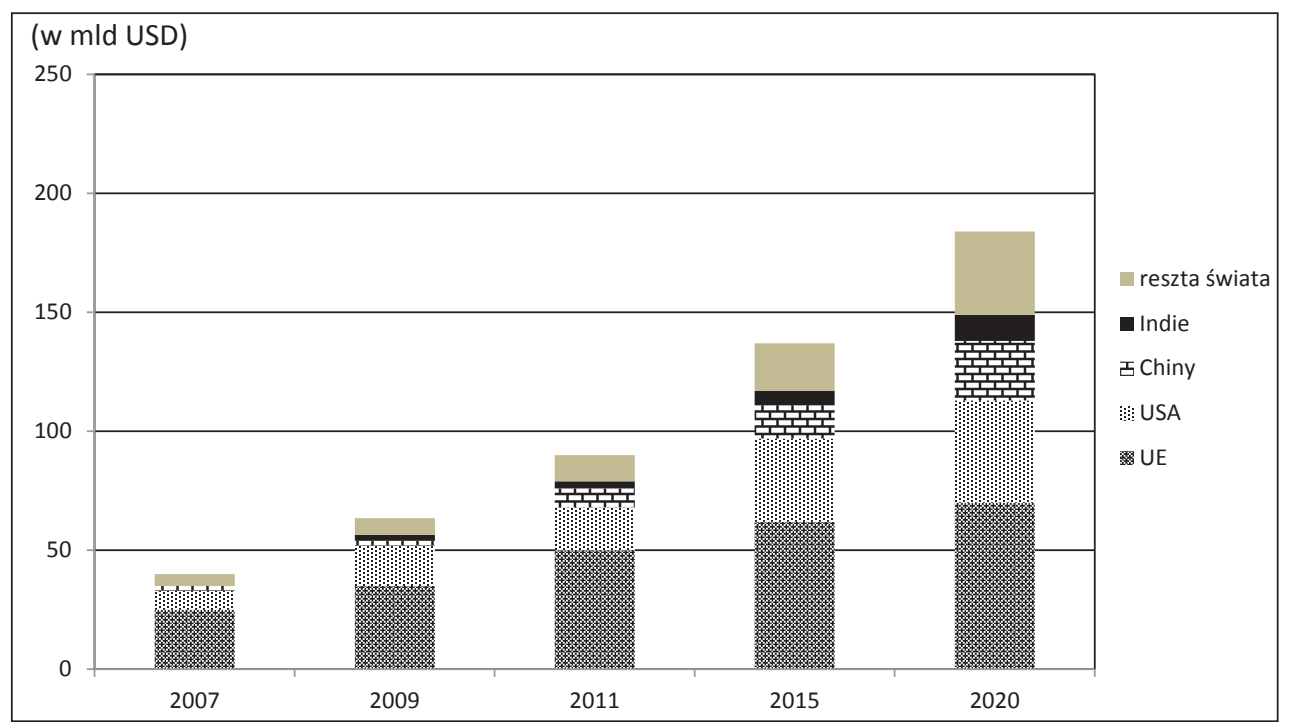

Ryc. 4. Światowe dotacje na energię ze źródeł odnawialnych w rozbiciu na regiony w 2011 roku (w mld USD)

Źródło: Wyzwania i polityka w zakresie energii, sprawy przedłożone przez Komisję na posiedzenie Rady Europejskiej w dniu 22 maja 2013 r. 
WSPIERANIE ROZWOJU OZE W POSZCZEGÓLNYCH KRAJACH UE

Kryzys gospodarczy spowodował, iż kraje członkowskie w celu jego przezwyciężenia postanowiły uzyskać oszczędności poprzez ograniczenie wsparcia rozwoju sektora energetyki odnawialnej. Dotowanie i subsydiowanie sektora OZE w konfrontacji z rosnącym bezrobociem i rosnącym zadłużeniem zostało ograniczone. Jednocześnie nagłe zmiany w systemach wsparcia, w niektórych przypadkach mające moc wsteczną, przyczyniły się do niepewności inwestorów i ograniczenia inwestycji w tego typu źródła. Przedsiębiorcy zaczęli wstrzymywać się z inwestycjami, wiedząc, że prawo może się zmienić, ale nie wiadomo dokładnie, w jakim kierunku.

W większości krajów członkowskich dotacje te są wyższe niż koszty produkcji, co powoduje, iż produkcja energii z OZE jest opłacalna. W przypadku lądowej energii wiatrowej dotacje powyżej kosztów produkcji energii utrzymują się: w Szwecji, Wielkiej Brytanii, na Łotwie, w Estonii, Rumunii, Czechach, Polsce, na Litwie, Słowacji, w Słowenii, we Włoszech, na Cyprze i w Belgii (ryc. 5).

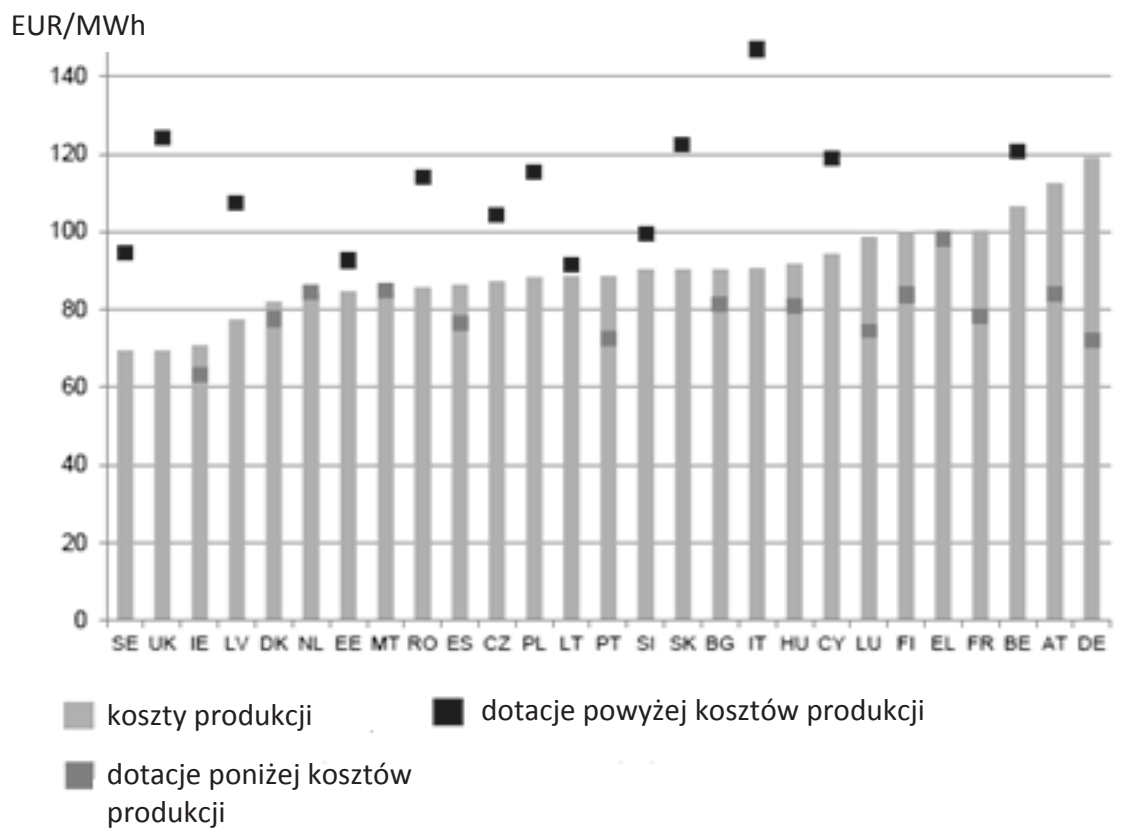

Ryc. 5. Koszty produkcji energii a dotacje na lądową energię wiatrową (średnie, w EUR/MWh) w 2011 roku

Źródło: Europejskie priorytety w zakresie energii, prezentacja J.M. Barroso, przewodniczącego Komisji Europejskiej, na szczyt Rady Europejskiej w dniu 22 maja 2013 r. 
W przypadku energetyki słonecznej dotacje te są wyższe w Hiszpanii, na Cyprze, w Portugalii, w Grecji, we Włoszech. Fotowoltaika nadal należy do drogich technologii, której bez wsparcia państwa trudno byłoby konkurować z konwencjonalnymi źródłami energii (ryc. 6).

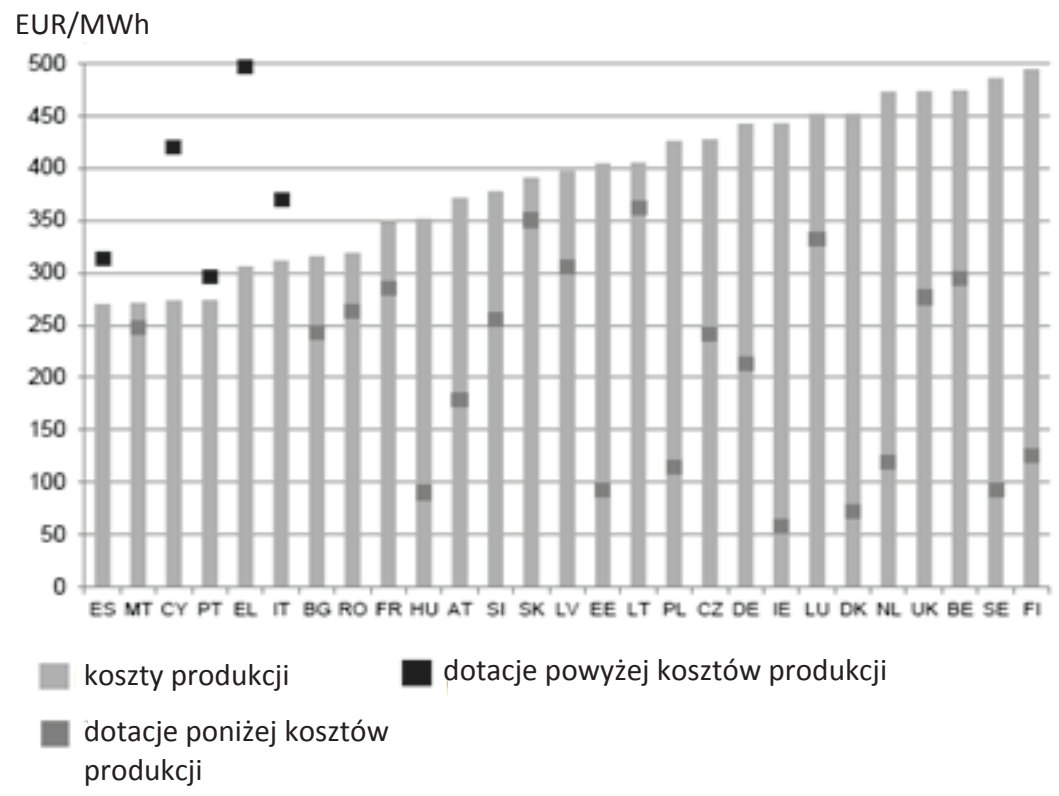

Ryc. 6. Koszty produkcji energii a dotacje na energię słoneczną (średnie, w EUR/MWh) w 2011 roku Źródło: Europejskie priorytety w zakresie energii, Prezentacja J.M. Barroso, przewodniczącego Komisji Europejskiej, na szczyt Rady Europejskiej w dniu 22 maja 2013 r.

Działania polegające na ograniczeniu subsydiowania sektora OZE, a w konsekwencji spowolnieniu rozwoju OZE, w największym stopniu wystąpiły w Hiszpanii, Niemczech i Czechach, ale również we Włoszech, Bułgarii, Wielkiej Brytanii.

Hiszpania była pierwszym państwem UE, które przyznało, że nie stać go na dalsze wspieranie nowych inwestycji w odnawialne źródła energii przy tak ogromnym poziomie subsydiowania. Państwo to jeszcze do 2011 roku należało do światowej i europejskiej czołówki pod względem wykorzystywania energii odnawialnej. Udział energii pochodzącej z OZE w konsumpcji energii elektrycznej przekroczył w tym kraju 30\%. Należy podkreślić, iż Hiszpania chciała stać się liderem pod względem wykorzystania OZE, upatrując w tym sektorze szanse na niezależność energetyczną. Ponadto subsydiowanie rozwoju farm wiatrowych i ogniw fotowoltaicznych miało uczynić z energetyki odnawialnej nowe źródło wzrostu gospodarczego i stworzyć nowe miejsca pracy (Hiszpania nie będzie liderem w wiatrowniach, 2012). Kryzys gospodarczy jednak zweryfikował priorytety gospodarcze, czego skutkiem jest niemal całkowite wstrzymanie w 2013 roku inwestycji w odnawialne źródła energii w tym kraju. 
Z podobnymi problemami co Hiszpania, muszą sobie radzić Włochy, które reformują system rządowej pomocy dla energii odnawialnej, gdyż dotychczas funkcjonujące ustawy stają się zbyt kosztowne. Dotychczasowy system subsydiów dla energetyki odnawialnej spowodował, iż podaż przekroczyła popyt. Włochy to kolejne państwo, które zdecydowało się zreformować system subsydiów dla energetyki odnawialnej (System wsparcia dla energetyki odnawialnej we Włoszech potrzebuje zmian, 2013).

W Czechach również pojawił się problem z subsydiowaniem OZE, będący skutkiem kryzysu gospodarczego. System wsparcia FiT dla energetyki słonecznej w Czechach został uruchomiony w 2006 roku w związku z tym, iż ustawa o promocji OZE nałożyła na sprzedawców obowiązek kupna energii elektrycznej wytwarzanej przez elektrownie słoneczne. Cena wyprodukowanej energii była kilkakrotnie wyższa od ceny rynkowej. Dodatkowo producentów energii odnawialnej zwolniono z podatku dochodowego na okres 5 lat od momentu podłączenia ich instalacji do sieci. W systemie subwencji przewidziano mechanizm korygujący, polegający na spadku dopłat o 5,0\% rocznie (Status of Photovoltaics in the European Union New Member States, 2011). Zakładano bowiem, iż w miarę rozwoju technologii fotowoltaicznych koszt wytworzenia energii będzie coraz niższy. Jednak ceny ogniw fotowoltaicznych spadały znacznie szybciej, niż zakładano. W tych okolicznościach dopłaty, które miały gwarantować zwrot inwestycji w ciągu 11 lat, pozwalały na osiągniecie tego zwrotu już po upływie 4 lat. Uruchomienie systemu FiT spowodowało gwałtowny wzrost ilości i mocy instalacji fotowoltaicznych w Czechach. Nastąpił skokowy wzrost liczby elektrowni słonecznych z niespełna 1500 jeszcze w 2006 roku do blisko 13 tys. w 2010 roku. W warunkach kryzysu gospodarczego ten gwałtowny wzrost ilości mocy instalacji fotowoltaicznych stał się uciążliwy dla gospodarki Czech. Gwarantowana cena sprzedaży energii słonecznej oraz dotacje państwowe i unijne spowodowały bowiem presję na wzrost cen energii elektrycznej. Z kolei wzrost cen energii elektrycznej powodował wzrost cen innych dóbr konsumpcyjnych, co w warunkach kryzysu było bardzo niedogodne. Dlatego też w listopadzie 2010 roku w Czechach znowelizowano prawo o wsparciu dla energii pochodzącej ze źródeł odnawialnych. Wprowadzono zapisy ograniczające dotacje jedynie do paneli słonecznych umieszczonych na dachach lub ścianach budynków oraz pozbawiające tych dotacji instalacje niepodłączone do sieci (Solar subsidies cut by more than half, 2011). Zniesiono pięioletni okres „wolności podatkowej” dla producentów energii odnawialnej.

W przypadku Niemiec podstawowym motywem ograniczenia dotacji na rozwój systemów fotowoltaicznych był wpływ tych dotacji (podobnie jak w Czechach) na wzrost cen energii elektrycznej, a tym samym na wzrost dóbr konsumpcyjnych w wielu branżach przemysłowych (Motowidlak, 2012). Wzrost tych cen odczuły także gospodarstwa domowe.

Oprócz ograniczenia krajowych systemów wparcia w czasie kryzysu gospodarczego pojawiło się jeszcze jedno zagrożenie dla rozwoju unijnego sektora energetyki odnawialnej. Nasiliła się bowiem bardzo silna ekspansja rynkowa Chin w tym sektorze, która obniżyła konkurencyjność unijnej energetyki odnawialnej. Podkreślić należy, iż w 2011 roku z Chin pochodziło 4 z 10 największych na świecie producentów turbin wiatrowych. Turbiny te były o ok. 15-20\% tańsze niż europejskie (Chińskie wiatraki zaleja Europę, 2011). Ze względu na bardzo korzystne pożyczki dla producentów instalacji fotowoltaicznych ich ceny 
spadły w Chinach o 30-40\% w 2011 roku, a udział tego kraju w ich światowej produkcji wzrósł aż do 57\%, podczas gdy w Unii Europejskiej technologia ta nadal jest droga. Tylko w Niemczech na skutek konkurencji chińskiej (oraz zmniejszenia subwencji rządowych) w 2012 roku zbankrutowało czterech producentów instalacji fotowoltaicznych, czyli Solon SE, Solar Millenium AG, Solarhybrid AG oraz Q-Cells (Motowidlak, 2012).

\section{ZAKOŃCZENIE}

Współcześnie energetyka oparta na źródłach odnawialnych w UE napotyka wiele barier utrudniających jej rozwój, zwłaszcza bariery finansowe, bariery natury administracyjnej, bariery lokalizacyjno-infrastrukturalne. Istniejące bariery wpływają na zwiększenie ryzyka inwestycyjnego, co przenosi się bezpośrednio na koszt energii elektrycznej z tych źródeł, który jest zazwyczaj wyższy niż w przypadku energii pozyskiwanej z konwencjonalnych źródeł energii.

Ambitny plan Unii Europejskiej pokrycia potrzeb energetycznych w znacznym stopniu z energii ze źródeł odnawialnych wywołał potrzebę tworzenia uwarunkowań prawnych w zakresie wspomagania różnych kierunków wykorzystywania odnawialnych źródeł energii. Unia Europejska dołożyła starań, by stworzyć instrumenty prawne promujące wykorzystanie OZE, wprowadzając w życie wiele dyrektyw. W celu zrealizowania ambitnego celu kraje członkowskie wprowadziły określone systemy wspomagające rozwój OZE, które różnią się między sobą. Niektóre z nich bazują na systemie cen gwarantowanych, zielonych certyfikatów, przetargów, inne zaś opierają się głównie na dotacjach i subwencjach lub zwolnieniach podatkowych.

Można zauważyć, że w krajach, które pierwotnie dofinansowywały i dotowały rozwój energetyki odnawialnej, nastąpił jej szybki rozwój, np. w Niemczech istniejący program rządowy dotyczący energetyki wiatrowej i stosowanie systemu cen gwarantowanych sprawił, iż w ciągu kilkunastu lat kraj ten stał się potęgą światową w tym sektorze.

Kryzys gospodarczy wywołał jednak dyskusję w całej Unii Europejskiej na temat kosztów związanych z produkcją energii elektrycznej z odnawialnych źródeł energii. Walka $\mathrm{z}$ bezrobociem i długiem publicznym, a także spadająca konkurencyjność unijnej gospodarki, która również powiązana jest z wysokim kosztami energii elektrycznej, postawiła wiele krajów (nawet liderów w tej branży) w sytuacji przymusu ograniczenia wsparcia dla tych źródeł energii.

Wydaje się zatem, iż dalszy rozwój energetyki odnawialnej w UE, a także osiągnięcie $20 \%$ jej udziału w bilansie energetycznym UE, zależeć będzie od koniunktury gospodarczej UE, sposobu wyjścia z kryzysu gospodarczego przez poszczególne kraje członkowskie, ale przede wszystkim od możliwości dalszego jej wspierania. 


\section{Literatura \\ References}

Chińskie wiatraki zaleja Europę (2011) (2014, 13 października). Pozyskano z http://ioze.pl/energetyka-wiatrowa/aktualnosci/hinskie-wiatraki-zaleja-europe

Dyrektywa Parlamentu Europejskiego i Rady w sprawie promowania stosowania energii ze źródel odnawialnych (2008). Bruksela, KOM (2008), 19 wersja ostateczna 2008/0016 (COD).

EU Energy, transport and environment indicators - 2013 edition. Luxembourg: Publications Office of the European Union, 2013.

Glachant, J.M., Lévêque, F. (2009). Electricity Reform in Europe. Towards a Single Energy Market. UK, Notrthampton, MA, USA: Edward Elgar.

Hiszpania nie będzie liderem w wiatrowniach. Rzeczpospolita, 5 lutego 2012.

Komunikat Energia odnawialna: istotny uczestnik europejskiego rynku energii (2012). COM (2012), 271.

Lewandowski, W.M. (2006). Proekologiczne odnawialne źródła energii. Warszawa: Wydawnictwa Naukowo-Techniczne.

Ligus, M. (2010). Efektywność inwestycji w odnawialne źródła energii. Analiza kosztów i korzyści. Warszawa: Wydawnictwa C e DeWu.

Meadows, D.H., Meadows, D.I., Randers, J., Behrens, W. W. (1972). The Limits to Growth. Abstract Established by Eduard Pestel. A Report to The Club of Rome. New York: Universe Books.

Motowidlak, T. (2012). Wpływ kryzysu finansowego strefy euro na rozwój sektora energii odnawialnej w UE. Acta Universitatis Lodziensis, Folia Oeconomica, 273.

National Overall Share and Targets for the Share of Energy from Renewable Sources in Gross Final Consumption of Energy in 2020. (2013, 25 września). Pozyskano z http://ec.europa.eu/energy/ renewables/targets_en.htm

Pach-Gurgul, A. (2012). Jednolity rynek energii elektrycznej w Unii Europejskiej w kontekście bezpieczeństwa energetycznego Polski. Warszawa: Difin.

Pyka, J. (red) (2007). Szanse i zagrożenia rozwoju rynku energetycznego w Europie i Polsce. Katowice: Wydawnictwo Akademii Ekonomicznej w Katowicach.

Solar subsidies cut by more than half (2011). The Guardian, 28th October 2011.

Status of Photovoltaics in the European Union New Member States 2010 (2011). Warszawa: Warsaw University of Technology.

System wsparcia dla energetyki odnawialnej we Włoszech potrzebuje zmian (2013, 13 listopada). Pozyskano z http://www.radanpre.pl/index.php?option=com_content\&view=article\&id=411:system-wsparcia-dla-energetyki-odnawialnej-we-woszech-potrzebuje-zmian\&catid=14: wiadomociklimatyczno-energetyczne\&Itemid $=44$

Wyzwania i polityka w zakresie energii (2013). Sprawy przedłożone przez Komisję na posiedzenie Rady Europejskiej w dniu 22 maja 2013.

Zielona księga. Ramy polityki w zakresie klimatu i energii do roku 2030 (2013, 13 listopada). Pozyskano z http://eur lex.europa.eu/LexUriServ/LexUriServ.do?uri=COM:2013:0169:FIN:PL:PDF

Agnieszka Pach-Gurgul, doktor nauk ekonomicznych, adiunkt w Katedrze Międzynarodowych Stosunków Gospodarczych w Uniwersytecie Ekonomicznym w Krakowie. Autorka książki Jednolity rynek energii elektrycznej w Unii Europejskiej w kontekśsie bezpieczeństwa energetycznego Polski i rozdziałów w książkach o tematyce międzynarodowych stosunków gospodarczych oraz wielu naukowych artykułów dotyczących przede wszystkim: przemian w polskiej i światowej energetyce, bezpieczeństwa energetycznego, wspólnotowej (unijnej) polityki energetycznej, procesu tworzenia jednolitego rynku energii oraz wyzwań ekologicznych dla współczesnej energetyki. 
Agnieszka Pach-Gurgul, holds a Ph.D. title in Economic Sciences and is an assistant professor in the Department of International Economic Relations at the Cracow University of Economics. She is the author of the book entitled Single Electricity Market in the European Union in the Context of Polish Energy Security and many academic articles and chapters in books, particularly concerning the following topics: changes in Polish and world power sector; energy security; European Union energy policy; the single energy market; and the challenges for contemporary ecological energy.

\section{Adres/address:}

Uniwersytet Ekonomiczny w Krakowie

Katedra Międzynarodowych Stosunków Gospodarczych

ul. Rakowicka 27, 31-510 Kraków, Polska

e-mail: apach@uek.krakow.pl 